\title{
VYBRANÉ PROBLÉMY IMPLEMENTÁCIE MODELU RIADENIA STRATEGICKEJ A OPERATÍVNEJ VÝKONNOSTI PODNIKOVÝCH PROCESOV
}

\section{Marcela Koval'ová}

Kl’účové slová:

Výkonnost'. Strategická výkonnost'. Operatívna výkonnost'. Podnikový proces. Model riadenia výkonnosti. Implementácia.

\section{Key words:}

Performance. Strategic Performance. Operative Performance. Business Process. Model of Performance Management. Implementation.

\begin{abstract}
Abstrakt
Príspevok sa zaoberá vybranými problémami implementácie modelu riadenia strategickej a operatívnej výkonnosti podnikových procesov. Autorka na základe navrhnutého modelu riadenia strategickej a operatívnej výkonnosti podnikových procesov a na základe jeho verifikácie vo vybranom podniku navrhuje kl'účové predpoklady implementácie modelu riadenia výkonnosti pre potreby podnikovej praxe a identifikuje niekol'ko problémov, ktoré počas zavádzania modelu nastali a ktoré môžu i v budúcnosti predstavovat' potenciálne bariéry implementácie modelu riadenia výkonnosti v d’alších podnikoch.
\end{abstract}

\begin{abstract}
This article deals with selected issues of implementation of the model of management of strategic and operative performance of business processes. The author in pursuance of the proposed model of management of strategic and operative performance of business processes and verifies this model in one of the chosen company. Author proposes the key assumptions of the model in terms of business practice and clarifies several issues that may be in future the potential barriers of implementation of this model in other enterprises.
\end{abstract}

\section{Úvod}

Model riadenia strategickej a operatívnej výkonnosti podnikových procesov predstavuje základný rámec, metodiku pre integrované meranie výkonnosti podnikov na krátkodobej i dlhodobej úrovni.

Podl'a Ďud'áka (1999) „systém (sústava) je určitou abstrakciou reálneho objektu, je obecným označením pre ucelenú čast' prostredia, ktorú možno definovat' určitými vlastnost'ami. Model môže predstavovat' zobrazenie a možnú realizáciu určitej teórie a potom má všetky vlastnosti systému.“ Prno (2002, s. 94) píše, že „,model akéhokol’vek zložitého systému tiež je systémom (a nezriedka vel'mi zložitým), ktorý má fyzickú realizáciu zapísanú pomocou slov, číslic, matematických znakov, grafických zobrazení a podobne. Model je fyzický alebo znakový systém, ktorý má objektívnu podobnost' so skúmaným systémom vo vzt'ahu k funkčným a často i štruktúrnym charakteristikám, ktoré sú predmetom skúmania.“

Výkonnost' podniku môžeme definovat' ako schopnost' podniku dosiahnut' požadované ciele, pričom rôzne skupiny v podniku (vlastníci, manažéri, zamestnanci) môžu mat' o výkonnosti rôzne predstavy. Množstvo l’udí, predovšetkým laikov, používa rôznorodé definície 
a vymedzenia pojmu výkonnost'. Pojem výkonnosti pritom nie je jednoznačne vymedzený. Na stránkach odbornej literatúry je možné v poslednej dobe nájst' celú záplavu modelov či sústav ukazovatel'ov doporučených na meranie podnikovej výkonnosti. Väčšinou však v nich nie je pojem výkonnosti definovaný. [Macurová, 2005, s. 196]

Rašner [2005, s. 50] tvrdí, že podniková výkonnost' a efektívnost' súvisí s budovaním jeho dlhodobej konkurencieschopnosti. Ďalej definuje pojem výkonnost', ktorý spája s konkurencieschopnost'ou. Pojem konkurenčnost' podl'a autora vyrástol z trhovej reality, bez nej by strácal zmysel. Pojem vyjadruje trhový potenciál podniku v boji o postavenie na trhu s inými podnikmi. Výsledkom tohto boja je schopnost' dosahovat' dobré postavenie na trhu a na tej úrovni dosahovat' zodpovedajúcu prosperitu po určitú dobu, najlepšie nadlho. Takýto podnik je konkurencieschopný a výkonný.

\section{Model riadenia strategickej a operatívnej výkonnosti podnikových procesov}

Návrh modelu riadenia strategickej a operatívnej výkonnosti vychádza z definície modelu, ktorá hovorí, že model vzniká zovšeobecnením, formalizáciou objektu. Popisuje základné prvky a väzby medzi operatívnou a strategickou výkonnost'ou podnikových procesov. Podnikové procesy predstavujú pomerne diskutovanú problematiku. Každý podnik je vo svojej podstate súborom podnikových procesov. Výkonnost' podniku vo vel'kej miere vytvárajú tri základné zložky: podnikové procesy, zamestnanci (l'udia) a uplatňované metódy riadenia (štýl riadenia podniku, využívané metódy, koncepcie a prístupy, ale tiež používané prístroje, postupy a technológia).

Podnikové procesy často rozhodujú o výkonnosti podniku, výkonnost' podnikových procesov napomáha zvyšovanie celkovej výkonnosti podniku. Podnikové procesy sú čast'ou komplexnej výkonnosti podniku, ktorú rozdel'ujeme do troch úrovní: celková výkonnost' podniku, výkonnost' podnikových procesov a výkonnost' jednotlivých zamestnancov alebo ich tímov. Dlhodobá výkonnost' podniku vyžaduje integrované riadenie strategickej i operatívnej oblasti výkonnosti, spojené is implementáciou strategického modelu najlepšie metódou Balanced Scorecard. Pri návrhu modelu riadenia strategickej a operatívnej výkonnosti som použila niektoré princípy metódy BSC, napríklad pohl'ad na podnik ako komplex štyroch perspektív: finančnej, zákazníckej, interných procesov a učenia sa a rastu. Model riadenia strategickej a operatívnej výkonnosti podnikových procesov predstavuje základný rámec pre meranie výkonnosti podnikov na krátkodobej i dlhodobej úrovni. Nepokúšala som sa navrhnút' úplne nový prístup k meraniu výkonnosti, ktorý kopíruje už vzniknuté koncepcie a metódy. Mojou snahou je poskytnút podnikom metodiku, praktický návod (model) aplikácie doterajších i nových poznatkov v oblasti merania a hodnotenia výkonnosti podniku, teda taký prístup k výkonnosti, ktorý podporuje orientáciu podniku nielen na jeho okamžitú (krátkodobú) výkonnost' ale i výkonnost' v dlhodobom meradle (strategickú výkonnost'). Model môže byt' návodom na meranie výkonnosti, nevyžaduje však dramatické zmeny $\mathrm{v}$ riadení podniku ani vylúčenie doteraz používaných a implementovaných metód riadenia podniku (podnik napríklad môže mat' zavedený systém manažérstva kvality alebo sledovat' kvalitu svojich produktov prostredníctvom benchmarkingu). Model je skôr snahou o prepojenie jednotlivých prístupov tak, aby výsledkom bola komplexná výkonnost' celého podniku.

Model riadenia výkonnosti má dve vzájomne prepojené oblasti: operatívnu a strategickú. 


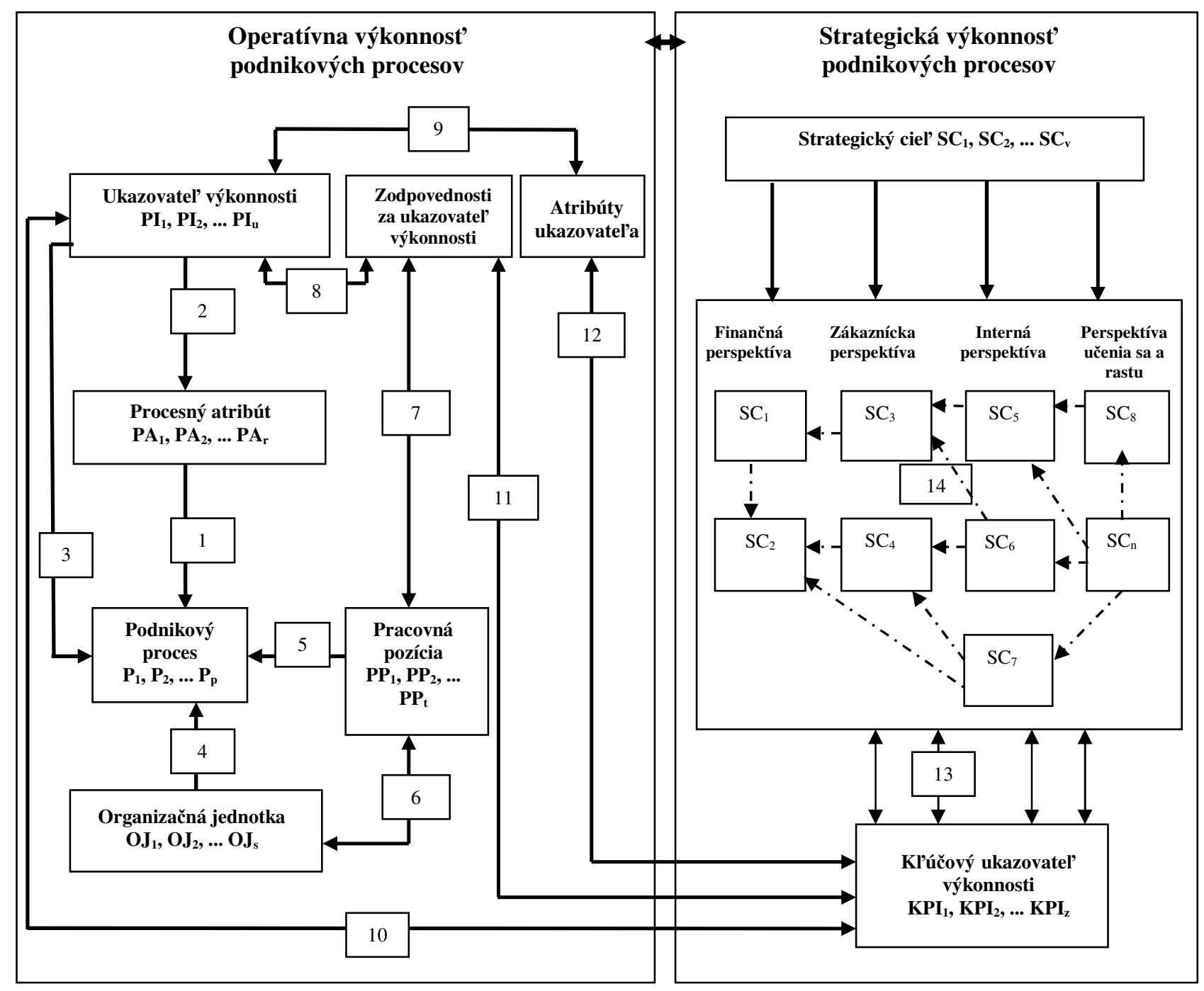

Obrázok 1 Model riadenia strategickej a operatívnej výkonnosti podnikových procesov Prameň: Vlastné spracovanie.

Obrázok 1 graficky prezentuje model riadenia výkonnosti podnikových procesov a znázorn̆uje jednotlivé prvky riadenia výkonnosti podnikových procesov spolu s ich vzájomnými väzbami v strategickej aj operatívnej oblasti.

Operatívna výkonnost' podnikových procesov je charakterizovaná týmito prvkami: podnikové procesy, procesné atribúty, ukazovatele výkonnosti, zodpovednosti za ukazovatele výkonnosti a atribúty ukazovatel'ov, organizačné jednotky ako aj pracovné pozície. Podnikový proces predstavuje sled nadväzujúcich činností, ktoré transformujú požadované vstupy na určité výstupy. Procesným atribútom rozumieme charakteristiku alebo vlastnost' priradenú podnikovému procesu alebo určitej činnosti procesu. Ukazovatel' výkonnosti je taký ukazovatel', ktorým sa meria a hodnotí výkonnost' daného procesu. Ukazovatele výkonnosti sú priradené podnikovým procesom prostredníctvom procesných atribútov. Ak zvolíme ako charakteristiku procesu napríklad jeho kvalitu, môžeme ju merat' prostredníctvom ukazovatel'a ako počet alebo percento nepodarkov z celkového počtu resp. množstva výstupov procesu. Ukazovatele výkonnosti sú tiež charakterizované určitými atribútmi charakteristikami. Ak k procesu je priradená jeho charakteristika - procesný atribút, 
i k ukazovatel'u výkonnosti je priradená jeho charakteristika, vlastnost' - atribút ukazovatel'a. Atribútom ukazovatel'a - jeho charakteristikou môže byt' napríklad jeho vzt'ah k strategickému ciel'u, vzt’ah k procesu, stanovená ciel'ová hodnota, vzorec pre výpočet a podobne. V rámci týchto atribútov sa nachádzajú i zodpovednosti za ukazovatele zodpovednost' za definovanie ukazovatel'a, za definovanie ciel'ovej hodnoty, za zaznamenávanie priebežných hodnôt a za hodnotenie ukazovatel'a výkonnosti. Zodpovednosti však predstavujú mimoriadne podstatný atribút, preto sú popisované ako samostatný prvok v oblasti modelu riadenia výkonnosti podnikových procesov.

Strategická oblast' výkonnosti predstavuje súbor strategických ciel'ov a ich ukazovatel'ov. V modeli je využitý jeden z princípov metódy Balanced Scorecard, ktorým je rôznorodý pohl'ad na výkonnost' podniku (z pohl'adu financií, zákazníka, procesov i zamestnancov), preto sú strategické ciele rozdelené do štyroch perspektív. Strategickým ciel'om rozumieme budúci žiaduci stav, ktorý chce podnik dosiahnut' a ktorý je meratel'ný určitými kvalitatívnymi alebo kvantitatívnymi ukazovatel'mi. V strategickej oblasti sú podstatným prvkom i klúčové ukazovatele výkonnosti, teda ukazovatele výkonnosti podniku na strategickej úrovni. Kl'účovým ukazovatel’om výkonnosti (Key Performance Indicator) rozumieme taký kvalitatívny alebo kvantitatívny ukazovatel', ktorý slúži k meraniu naplnenia strategických ciel'ov. Ide o každý ukazovatel' výkonnosti definovaný v operatívnej oblasti výkonnosti, ktorý sleduje mieru naplnenia definovaného strategického ciel'a.

Väzbu medzi strategickou a operatívnou výkonnost'ou podnikových procesov predstavujú práve kl'účové ukazovatele výkonnosti (KPI). KPI slúžia na hodnotenie miery splnenia strategických ciel’ov, v operatívnej oblasti ako ukazovatele výkonnosti plnia úlohu indikátorov výkonnosti podnikových procesov. V modeli je vzájomná súvislost' medzi strategickou a operatívnou výkonnost’ou a medzi ich jednotlivým prvkami vyznačená orientovanou úsečkou. Väzby v modeli sú vyznačené číslami pri orientovaných úsečkách. V modeli riadenia strategickej a operatívnej výkonnosti podnikových procesov bolo identifikovaných štrnást’ väzieb medzi jednotlivými prvkami. Základnou väzbou je prepojenie (vzt'ah) strategickej a operatívnej oblasti výkonnosti.

\section{Kl’účové predpoklady implementácie modelu riadenia strategickej a operatívnej výkonnosti podnikových procesov}

Na základe navrhnutého modelu riadenia strategickej a operatívnej výkonnosti podnikových procesov som navrhla klúčové predpoklady implementácie modelu riadenia výkonnosti pre potreby podnikovej praxe a identifikovala som tiež niekol'ko problémov, ktoré počas implementácie nastali a ktoré môžu i v budúcnosti predstavovat' potenciálne bariéry implementácie modelu riadenia výkonnosti v podniku.

Na základe skúseností pri verifikácii navrhnutého modelu riadenia strategickej a operatívnej výkonnosti podnikových procesov v podmienkach konkrétneho podniku z oblasti strojárstva som definovala niekol'ko kl'účových prvkov (predpokladov), z ktorých model riadenia výkonnosti podnikových procesov vychádza:

1. potreba implementácie procesného riadenia a riadenia výkonnosti vodniku a pochopenie jej nevyhnutnosti,

2. vytvorenie pracovného tímu pre implementáciu procesného riadenia a riadenia výkonnosti v podniku,

3. existencia procesného riadenia $\mathrm{v}$ podniku, procesný model podniku, 
4. správna identifikácia podnikových procesov a popísanie činností jednotlivých procesov, posúdenie relevantnosti procesov a prípadná reorganizácia na dosiahnutie vysokej výkonnosti,

5. vyjasnenie kompetencií a zodpovedností za podnikové procesy,

6. systematické riadenie podnikových procesov a ich výkonnosti, vol'ba vhodných procesných atribútov a ukazovatel’ov výkonnosti,

7. vhodná a aktuálna podniková stratégia,

8. pravidelné preskúmanie a aktualizácia registra výkonnosti, riadenie strategickej výkonnosti,

9. zvyšovanie strategickej a operatívnej výkonnosti podnikových procesov,

10. vytvorenie predpokladov pre zmenu myslenia zamestnancov, komunikácia zámerov podniku v smere $\mathrm{k}$ zamestnancom,

11. zladenie procesu prípravy a implementácie procesného riadenia a riadenia výkonnosti s operatívnou činnost'ou podniku,

12. prepojenie procesného riadenia a riadenia výkonnosti s inými systémami riadenia podniku (systém manažérstva kvality a iné),

13. softvérová podpora.

Prvou a základnou podmienkou implementácie procesného riadenia a riadenia strategickej a operatívnej výkonnosti je potreba implementácie procesného riadenia a riadenia výkonnosti v podniku a pochopenie jej nevyhnutnosti. O potrebe a následne i projekte implementácie procesného riadenia a riadenia výkonnosti v podniku rozhoduje vrcholový manažment, pretože je základným nositel’om zmien v podniku a samozrejme rozhoduje o alokácii zdrojov pre jednotlivé projekty. Vrcholový manažment a vedúci zamestnanci musia byt' presvedčení o potrebe a nevyhnutnosti takejto zmeny a zároveň byt' príkladom pre zamestnancov na ostatných úrovniach riadenia. Vrcholový manažér, ktorý nepodporuje zavedenie procesného riadenia a riadenia výkonnosti v podniku iba t’ažko motivuje zamestnancov, aby projekt brali vážne a výsledkom potom nebude účinne a efektívne implementovaný procesný model a model riadenia výkonnosti, ale iba d’alšia „formalita“, ktorá nepriniesla žiadnu pozitívnu zmenu.

Ak už v podniku existuje potreba implementovat' procesné riadenie a riadenie výkonnosti, vytvára vrcholový manažment pracovný (projektový) tím. Projektovým tímom v užšom význame (iba podnik samotný) je skupina vybraných zamestnancov, ktorí budú zodpovední za úspešnú implementáciu projektu v podniku. V prvej etape, ked' ešte nie sú známe, ktorí zamestnanci budú vlastníkmi jednotlivých procesov, predstavuje základ projektového tímu projektový manažér. Projektovým manažérom môže byt' vybraný vrcholový zamestnanec (manažér/vedúci oddelenia, riaditel'/vedúci úseku ap.), ktorý bude neskôr koordinovat' celý priebeh projektu z časového i obsahového hl'adiska a bude zodpovedný za komunikáciu s poradenskou organizáciou i za úspešnú implementáciu projektu. V d’alšej fáze, počas procesnej analýzy a modelovania procesov, sa súčast'ou projektového tímu stanú všetci vlastníci podnikových procesov. Okrem toho môžu byt' súčast'ou tímu i všetci vrcholoví zamestnanci, ak sa projektu zúčastňujú. V širšom význame predstavujú projektový tím všetci, ktorí sa nejako podiel'ajú na projekte implementácie procesného riadenia a riadenia výkonnosti. Okrem projektového manažéra a vlastníkov procesov tu patria i konzultanti poradenskej organizácie, konzultanti organizácie poskytujúcej softvér a tiež zamestnanci podniku, ktorí sú zapojení do iných projektov v podniku.

Ďalším predpokladom pre riadenie výkonnosti je existencia procesného riadenia v podniku. Vytvorením projektového tímu sa začína etapa procesnej analýzy a procesného modelovania, 
ktorej výsledkom je procesný model podniku. Z hl'adiska výkonnosti podniku nestačí iba vytvorit' procesný model ako súhrn procesov v podniku, je potrebné vytvorit' podmienky na to, aby identifikované podnikové procesy bolo možné riadit' a merat' ich výkonnost'. Základom je správna identifikácia podnikových procesov a dôsledné rozdelenie podnikových procesov. Procesy by nemali byt' iba rozdelené do jednotlivých funkčných úsekov, ale predovšetkým do kategórií (hlavné, podporné, externé) tak, aby bolo možné definovat', ktoré procesy sú zhl'adiska tvorby pridanej hodnoty pre zákazníka kl'účové. Po správnej identifikácii a kategorizácii podnikových procesov musí nasledovat' pomerne náročná etapa popisovania činností jednotlivých procesov, ako i posúdenie relevantnosti procesov a ich prípadná reorganizácia na dosiahnutie vysokej výkonnosti (odstránenie nedostatkov, korekcie, zlúčenie alebo rozdelenie procesu a podobne).

V d’alšej etape je predpokladom úspechu projektu správne priradenie vlastníkov pre jednotlivé podnikové procesy, vyjasnenie kompetencií a zodpovedností tak, aby žiadna činnost' „neostala visiet' vo vzduchoprázdne“" a aby v podniku neexistoval žiaden proces alebo činnost', za ktorú by nebol nik zodpovedný. V tejto fáze dochádza v rámci projektového tímu k najčastejším konfliktom a proces vyjasňovania právomocí a zodpovedností je pomerne časovo náročný, predovšetkým vtedy, ak v podniku existovali činnosti, o ktorých sa viedli spory z hl'adiska ich zaradenia k jednotlivým organizačným jednotkám (úsekom, oddeleniam a podobne).

Po vyjasnení zodpovedností a priradení l’udských zdrojov do procesného modelu etapa implementácie procesného riadenia nekončí, naopak, je potrebné zabezpečit', aby v podniku existoval jednotný systém pre prácu s podnikovými procesmi a tiež zabezpečit', aby táto práca bola nepretržitá. Častokrát nie je možné nájst' optimálny spôsob, ako by daný proces mal byt' vykonávaný. V tomto prípade môže platit', že ,prax ukáže“, akým spôsobom je najefektívnejšie proces vykonávat'. Ani vlastníci procesov by sa nemali spoliehat' na to, že opísaním procesu ich „práca“ končí. Naopak, procesný model nemá byt’ statický, ale dynamický pohl'ad na situáciu v podniku. Ak sa v priebehu určitého času ukáže, že podnikový proces je neefektívny alebo vyžaduje zmenu, v procesnom modeli musí byt' zmena zachytená, aby o nej vedeli zamestnanci, ktorých sa to týka. V tejto etape je tiež nevyhnutné zvolit' pre podnikové procesy procesné atribúty a ukazovatele ich výkonnosti, ktoré budú z hl'adiska výkonnosti podniku relevantné a vhodné a pre podnik nebude zát'ažou, ked' ich bude musiet' merat'.

Vhodnost' a aktuálnost' podnikovej stratégie je taktiež jednou z podmienok úspešnej implementácie projektu. Podniková stratégia musí vyjadrovat' najzásadnejšie a rozhodujúce problémy, ktoré sa týkajú prosperity a existencie podniku v budúcnosti. Jej nevhodnost' alebo neaktuálnost' môže spôsobit', že strategické ciele, ktoré ju kopírujú nebudú ozajstnými ciel'mi, ktoré chce podnik dosiahnut', ale iba formuláciami a celý projekt riadenia výkonnosti sa stane zbytočnost'ou, navyše často finančne a časovo nákladnou. Podobne ako musí byt' aktuálna podniková stratégia, musí byt' aktuálny a aktualizovaný i tzv. Register výkonnosti - spravidla súbor vo formáte .xls, ktorý združuje všetky náležitosti potrebné na implementáciu modelu riadenia výkonnosti podnikových procesov v podnikovej praxi. Ide $\mathrm{v}$ podstate o databázu všetkých podnikových procesov, strategických ciel'ov a kl’účových ukazovatel'ov výkonnosti, ktoré sa vzt'ahujú k riadeniu výkonnosti, a to na úrovni strategickej ako aj operatívnej.

Zvyšovanie výkonnosti podnikových procesov vychádza z jej merania a hodnotenia. Základným podnetom zvyšovania výkonnosti podnikového procesu môžu byt' nedostatočné výsledky procesu, ktoré vyplynuli z merania a hodnotenia ukazovatel'ov výkonnosti. Podnik však tvoria l'udia, zamestnanci. Bez ich nápadov a kreativity, ako i angažovanosti by každá 
zmena bola iba formálna, bez reálnych výsledkov. Vel'kou mierou sa na zvyšovaní výkonnosti podiel'a vrcholové vedenie a predovšetkým vytvorený systém motivácie a odmeňovania zamestnancov. Podnecovanie zlepšovatel'ských aktivít zamestnancov má byt' nepretržitou činnost'ou, o ktorej dôležitosti je vedenie presvedčené.

Nevyhnutnou podmienkou determinujúcou úspech alebo neúspech projektu je vytvorenie predpokladov pre zmenu myslenia zamestnancov. Podobne ako vrcholový manažment, i zamestnanci na všetkých úrovniach riadenia podniku by mali byt' stotožnení so zámermi a ciel'mi podniku. Prvým krokom je, že zamestnanci tieto zámery a ciele budú poznat', až potom ich môžu pochopit' a byt' o nich presvedčení. Jedným zo spôsobov, ako dosiahnut', aby zamestnanci poznali a pochopili zámery a ciele podniku i nevyhnutnost' implementácie projektu takéhoto rozsahu je komunikovat' s nimi, vysvetlit' im podstatu procesného riadenia a riadenia výkonnosti a ponúknut' im možnost' zvyšovania vedomostnej úrovne napríklad prostredníctvom školenia. Jedným z prínosov vytvorenia procesného modelu a jeho zavedenia do praxe je to, že umožňuje pochopit' úlohu jednotlivca v podniku a jeho podiel na celkovom výsledku podniku. Úspešnost' projektu vo vel'kej miere ovplyvňuje organizačná kultúra, predovšetkým jej zotrvačnost'. Nadšenie pre projekt a angažovanost' zamestnancov sú často dôležitejšie ako špičková poradenská organizácia, ktorá je iba prostriedkom dosiahnutia úspechu, nie jeho základom.

Jedným z kl’účových prvkov je i zladenie procesu prípravy a implementácie riadenia procesov a riadenia výkonnosti s operatívnou činnost’ou podniku. Správne načasovanie projektu môže výrazne ovplyvnit' to, či bude projekt „dotiahnutý do konca“. Ak by sa projekt takéhoto rozsahu a náročnosti realizoval napríklad v podniku zameranom na poradenstvo v oblasti účtovníctva a daní, určite by jeho začiatok nemal byt' naplánovaný na obdobie februára alebo marca, kedy sa všetci zamestnanci sústredia na tvorbu daňových priznaní a ukončenie minulého účtovného obdobia. V tomto prípade by sa totiž nedala očakávat' ich angažovanost' a ochota spolupracovat'. Obdobne, ak by sa projekt realizoval v podniku zameranom na pol'nohospodársku výrobu, počas mimoriadne náročného obdobia zberu úrody (august, september) by bol pravdepodobne odsúdený na neúspech.

Softvérová podpora riadenia podnikových procesov a ich výkonnosti je pri vel'kom množstve informácií, ktoré v sebe obsahuje procesný model i model výkonnosti nevyhnutnost'ou a základným predpokladom implementácie. Základným prínosom využitia softvérového nástroja je podpora správy a riadenia podnikových procesov a ich výkonnosti. Využitie softvérového nástroja umožní lepšie a rýchlejšie spracúvanie používaných informácií a dát a manipuláciu s nimi. Je to nevyhnutná podmienka realizácie zmien v podniku a zvyšovania jeho výkonnosti.

\section{Problémy implementácie navrhnutého modelu riadenia strategickej a operatívnej výkonnosti podnikových procesov vo vybranom podniku}

Počas verifikácie modelu riadenia strategickej a operatívnej výkonnosti podnikových procesov vo vybranom strojárskom podniku som identifikovala niekol'ko problémov, ktoré podl'a výrazne ovplyvňovali efektívnost' a úspešnost' implementácie modelu. Uvedené problémy majú spravidla významný vplyv na celý priebeh zavádzania modelu riadenia výkonnosti do praxe a bez ich poznania a pochopenia môže projekt vyzniet' iba ako formalita s neúspešným záverom. Zároveň som navrhla možné riešenia nasledujúcich problémov:

1. chýbajúca angažovanost' a presvedčenie zamestnancov na rôznych riadiacich úrovniach, 
2. nesprávne vybraní vlastníci procesov,

3. neúčast' vrcholového manažmentu,

4. rezistencia voči zmenám,

5. premotivovaný projektový manažér,

6. nejasnosti a výhovorky,

7. zmeny v harmonograme konzultácií,

8. časová náročnost' projektu implementácie procesného modelu a modelu výkonnosti.

Chýbajúca angažovanost’ a presvedčenie zamestnancov na rôznych riadiacich úrovniach Najčastejším problémom pri implementácii modelu riadenia výkonnosti podnikových procesov v praxi je chýbajúca angažovanost' a presvedčenie zamestnancov, nespolupráca alebo neochota zo strany vlastníkov procesov. Jej príčinou môže byt' fakt, že projekt prebieha súbežne s prevádzkou podniku. V praxi to znamená, že vlastníci procesov zabezpečujú výkon riadnych funkcií, vyplývajúcich im z náplne práce a zároveň koordinujú svojich podriadených pri konzultáciách alebo sa konzultácií sami zúčastňujú. Neochota zo strany vlastníkov procesov je samozrejme badatel’ná predovšetkým na začiatku a na konci pracovného týždňa. $\mathrm{Na}$ začiatku pracovného týždňa preto, lebo vtedy sa v podnikoch zvyčajne riešia operatívne pracovné porady a plány do d’alšieho týždňa a na konci preto, lebo pred ukončením práce v pracovnom týždni je potrebné doriešit' množstvo pracovných záležitostí. Nespolupráca (neochota) sa prelína i s d'alšími problémami pri implementácii modelu riadenia výkonnosti v podniku, a to je nesprávny výber vlastníkov procesov a neúčast' vrcholového manažmentu podniku či už v procese prípravy alebo i implementácie procesného riadenia a riadenia výkonnosti podnikových procesov.

\section{Nesprávne vybraní vlastníci procesov}

Vlastníkom procesu sa rozumie ten, kto proces zaviedol a nesie zaň celkovú zodpovednost'. Je zodpovedný tiež za zlepšovanie procesu, riadi, rieši a eliminuje systematické a náhodné vplyvy. Ako d’alší problém pri tvorbe a implementácii modelu riadenia výkonnosti sa javí nesprávny výber vlastníkov procesov. V slovenských podnikoch pravdepodobne stále pretrváva názor, že vlastníkovi procesu sa nemusí venovat' vel'ká pozornost'. Vlastníci procesov sú často vyberaní náhodne, alebo je táto „funkcia“ prisúdená jednému manažérovi, ktorý je potom zahltený nielen vlastnou prácou, ale neskôr aj prácou s procesmi. Takto vzniká predpoklad pre neochotu alebo odpor voči zžitiu sa s procesným riadením zo strany manažéra, čo sa následne prejaví v nezáujme aj jeho podriadených. Výsledkom je zavedený, ale nefunkčný systém riadenia podnikových procesov aj systém riadenia výkonnosti týchto procesov. Často sa stáva, že nesprávny výber vlastníka sa odhalí už pri konzultáciách k tvorbe procesného modelu a modelu riadenia výkonnosti, avšak pre nedostatok času a pre požiadavku ukončit' projekt k stanovenému dátumu sa daný stav už nezmení. Stáva sa tiež, že funkcia vlastníka procesu je pre niektoré procesy kumulovaná. Takéto riešenie nemusí byt' nevyhnutné negatívne, hoci prispieva k väčšiemu tlaku na vlastníka procesu, ktorý po čase môže stráca prehl'ad o jednotlivých procesoch a ich výsledkoch resp. výkonnosti. Riešením problému nesprávneho výberu vlastníkov by mohla byt' dôsledná príprava projektu aj realizácia workshopu, a to za účasti vrcholového manažmentu a d'alších vedúcich zamestnancov. Treba však brat' do úvahy, že vlastníkom procesu by mal byt' kl'účový manažér, zodpovedný za výsledok (produkt) celého procesu a výkonnost' procesu.

\section{Neúčast' vrcholového manažmentu}

Menej častým, i ked' v konečnom dôsledku závažným je problém neúčasti vrcholového vedenia podniku na tvorbe a implementácii procesného modelu i modelu riadenia výkonnosti podnikových procesov. Práve neúčast' a nepodiel'anie sa vrcholového vedenia podniku na 
projekte býva často značne demotivujúcim prvkom pri tvorbe a implementácii modelu riadenia výkonnosti podnikových procesov v podniku. Pre efektívnu tvorbu a implementáciu modelu je vhodné, aby každá nová konzultácia s vlastníkom procesu začala za účasti vrcholového vedenia (napríklad generálneho riaditel'a). Vrcholové vedenie je totiž schopné motivovat', inšpirovat', podporovat' a manažovat' zamestnancov, ako aj riešit' prípadné problémy týkajúce sa projektu, čo vzhl'adom na jeho časovú aj finančnú rozsiahlost' nie je zanedbatel'né. V projekte musí platit' pravidlo, že manažér je vždy aj členom tímu. Vedenie tak zároveň dáva zamestnancom pocit, že má záujem o výsledky projektu a vie ocenit' ochotu a iniciatívu zamestnancov. Niektorým zamestnancom projekt môže poskytnút' príležitost' na zviditel'nenie svojich schopností a snahy.

\section{Rezistencia voči zmenám - trvanie na zažitom spôsobe fungovania podniku}

Rezistencia voči zmenám predstavuje problém, kedy zamestnanci trvajú na zažitom spôsobe fungovania podniku bez toho, aby prijali a akceptovali zmenenú situáciu (alebo potrebu zmeny) v podniku. V praxi ide o situáciu, kedy zamestnanci nie sú ochotní akceptovat' pripravovaný projekt implementácie procesného riadenia a riadenia výkonnosti do existujúceho systému riadenia podniku a držia sa zaužívaných postupov. Tento problém býva viditel'ný nielen pri tvorbe procesného modelu a modelu výkonnosti, ale tiež vo fáze generovania riadiacej dokumentácie $\mathrm{z}$ vytvoreného procesného modelu. Riadiaca dokumentácia, ktorá vychádza z procesného modelu by mala byt' po akceptovaní vrcholovým manažmentom podniku záväzná pre všetkých zamestnancov podniku. Používanie novej riadiacej dokumentácie môže byt' pre zamestnancov v praxi omnoho náročnejšie, ako sa pôvodne predpokladalo, pravdepodobne preto, že rokmi zaužívané pravidlá a postupy sa najt'ažšie menia. Problémom nemusí byt' formálna zmena platných dokumentov, ale zotrvačnost' myslenia l'udí. Zamestnanci môžu nadobudnút' pocit, že projekt je zbytočný alebo nepotrebný a v takomto prípade je namieste, aby manažéri svojich podriadených správne motivovali. Výkonnost' procesov závisí na jednej strane od výkonných strojov, ale na druhej strane od výkonných zamestnancov.

\section{Premotivovaný projektový manažér}

Projektovým manažérom je zvyčajne zamestnanec podniku v niektorej riadiacej pozícii (manažér/vedúci oddelenia, riaditel'/vedúci úseku alebo inej organizačnej jednotky, zriedkavo to môže byt' i generálny riaditel' podniku). Jeho úlohou je riadit' a koordinovat' priebeh projektu implementácie modelu riadenia výkonnosti, a to tak z časového ako i z obsahového hl'adiska, d'alej komunikovat' s prizvanou poradenskou organizáciou, koordinovat' vlastníkov procesov, zabezpečit' realizáciu stanovených konzultácií a tiež zabezpečit' úspešnú implementáciu projektu v podnikovej praxi. Projektový manažér môže i nemusí byt' zodpovedný za procesný model ako jeho správca a je tiež zodpovedný za správnost' a používanie modelu riadenia výkonnosti podnikových procesov.

Premotivovanost' projektového manažéra môže predstavovat' d'alšie úskalie. Ide o situáciu, kedy projektový manažér preberá na seba zodpovednost' za celý priebeh implementácie procesného modelu aj modelu riadenia výkonnosti podnikových procesov. Extrémnym prípadom môže byt', ak projektový manažér vykonáva viacero úloh súčasne, a to i tie, za ktorých vykonávanie sú zodpovední iní. Premotivácia je pojem, ktorý sa najčastejšie vyskytuje v oblasti športu. Označuje sa ním stav, ked' zvyčajne mladí športovci pod vplyvom povzbudzovania divákov prekročia optimálnu úroveň angažovanosti potrebnú pre dosiahnutie dobrého výkonu. Výsledok premotivovanosti i napriek úsiliu (alebo práve napriek nemu) býva priemerný až podpriemerný. I projektový manažér, ak je premotivovaný a preberá na seba všetky úlohy (často neopodstatnene), môže získat' neúmerný pocit zodpovednosti, 
z ktorého vyplýva psychický stres pôsobiaci na celkový výsledok negatívne. Úlohou projektového manažéra by mala byt' koordinácia vlastníkov procesov pri zmenách a aktualizácii procesného modelu ako aj modelu riadenia výkonnosti procesov, vykonanie zmien a aktualizácií, príprava workshopov a stretnutí vlastníkov procesov, manažérov oddelení a vedúcich úsekov a podobne. Zvyčajne je alebo môže byt' vlastníkom procesu riadenia dokumentov a záznamov, riadenia interných auditov, nápravnej a preventívnej činnosti ako aj procesu preskúmania systému manažérstva kvality, d’alej tiež správcom procesného modelu, je zodpovedný za jeho tvorbu aj zmeny, riadi výstupy z procesného modelu, koordinuje meranie a hodnotenie výkonnosti procesov, tvorí a mení systém merania a hodnotenia výkonnosti procesov, prípadne zodpovedá za proces simulácie vybraných podnikových procesov.

\section{Nejasnosti a výhovorky}

Tvorbu a implementáciu modelu riadenia výkonnosti podnikových procesov v podniku môžu značne spomal'ovat' rôzne nejasnosti či výhovorky zamestnancov. Pri verifikácii navrhnutého modelu riadenia strategickej a operatívnej výkonnosti podnikových procesov vo vybranom podniku vystúpili do popredia tri skupiny výhovoriek (tabul'ka 1): výhovorky/nejasnosti týkajúce sa kompetencií, výhovorky/nejasnosti týkajúce sa schopností alebo vedomostí a výhovorky/nejasnosti týkajúce sa nedôvery voči projektu. Akékol'vek nejasnosti či výhovorky zvyčajne rieši a eliminuje projektový manažér.

Tabul'ka 1 Príklady nejasností či výhovoriek v procese implementácie projektu vo vybranom podniku

\begin{tabular}{|c|c|}
\hline Nejasnost'/výhovorka & Príklad \\
\hline \multirow[t]{2}{*}{ Nejasnost'/výhovorka týkajúca sa kompetencií } & „Nie som kompetentný hovorit’ o ...“ \\
\hline & „Toto musí/mal by povedat' ...“ \\
\hline \multirow{3}{*}{$\begin{array}{l}\text { Nejasnost'/výhovorka týkajúca sa schopností } \\
\text { alebo vedomostí }\end{array}$} & „Nenaštudoval som si ...“ \\
\hline & „Neviem to povedat' ...“ \\
\hline & „Neopýtal som sa XY ...“ \\
\hline \multirow{2}{*}{$\begin{array}{l}\text { Nejasnost'/výhovorka týkajúca sa nedôvery } \\
\text { voči projektu, neochoty }\end{array}$} & „Nemáme čas vykonávat' ...“ \\
\hline & „Tieto činnosti netreba popisovat', pretože ...“ \\
\hline
\end{tabular}

Prameň: Vlastné spracovanie.

Výhovorka týkajúca sa kompetencií jednotlivých zamestnancov by však nemala byt' relevantná, nakol'ko pred zavádzaním modelu riadenia výkonnosti podnikových procesov do systému riadenia podniku musí byt' jednoznačne jasné, ktorí zamestnanci sa budú zúčastňovat' na konzultáciách, pričom sa prihliada na ich kompetentnost' a tiež skúsenosti a pracovnú pozíciu v budúcnosti (či budú s modelom výkonnosti prichádzat' do styku, používat' ho alebo nie). Výhovorka týkajúca sa schopností alebo vedomostí býva často taktiež neopodstatnená, a zároveň mnohokrát spojená s d'alšou výhovorkou, a to neochotou zamestnancov podiel'at' sa na projekte. Znamená to, zamestnanec vedome sabotuje projekt tým, že na otázky konzultanta odpovedá záporne alebo slovom „,neviem“ prípadne „nepýtal som sa nadriadeného“ a podobne. V oboch prípadoch je ako riešenie vhodné, aby vedenie podniku prípadne projektový manažér prehodnotili výber zamestnanca (vlastníka procesu) a pri neochote vyplývajúcej z nedostatočnej motivácie prekonzultovali so zamestnancom možnosti riešenia.

\section{Zmeny v harmonograme konzultácií}

Neustále zmeny vo vopred stanovenom harmonograme konzultácií k tvorbe a implementácii modelu riadenia výkonnosti podnikových procesov prispievajú k zvyšovaniu napätia jednak na strane konzultantov poradenskej organizácie a tiež na strane zamestnancov. Existujú opodstatnené i neopodstatnené zmeny týkajúce sa harmonogramu konzultácií. Ideálne je, ak 
občasné zmeny v časovom harmonograme sú menšieho rozsahu a neovplyvnia tak čas trvania projektu ani náklady. Zmeny v harmonograme konzultácií môžu byt' však spôsobené i rôznymi nepredvídatel'nými udalost’ami, ktoré je potrebné vždy operatívne riešit' (náhle riešenie vzniknutých situácií v prevádzke podniku, živelné udalosti, ap.). Zmeny môžu nastat' i vplyvom vedomého odkladania konzultácií zo strany zamestnancov, vplyvom chorôb alebo absencií zamestnancov zainteresovaných v projekte alebo inými situáciami. Obvykle sa pred začiatkom projektu dohodnú presné pravidlá konzultácií, z ktorých sa tvoria zápisy o účasti zamestnancov ako aj obsahu konzultácie. Podpísaný zápis je dokladom pre zamestnanca o jeho účasti na konzultácii, ako aj o účasti konzultanta a pre vedenie je signálom, že projekt prebieha v stanovenom časovom harmonograme. Neustále odkladanie konzultácií môže za následok ustavičné ,začínanie odznova“ a nemožnost' vytvorenia a zavedenia modelu riadenia výkonnosti ako aj procesného modelu. Obyčajne sa tým predlžuje trvanie projektu a v konečnom dôsledku aj náklady na projekt, čo vedie k nespokojnosti na strane vedenia podniku a spätne i na strane zamestnancov, ktorí majú pocit nátlaku a časového stresu. Ideálnym riešením je dohoda o určitom počte alebo rozsahu odchýlok v harmonograme, ktoré je možné tolerovat' zo strany konzultanta aj zo strany manažmentu podniku. Pri prekročení odchýlok, teda pri väčšom počte zmien je nevyhnutné harmonogram prekonzultovat' a prípadne stanovit' nový, aby sa predišlo zbytočným komplikáciám.

Zmeny v harmonograme však nemusia byt' iba časové, ale tiež procesné. V tomto prípade nejde o zmenu dátumu konzultácie, ale jej obsahu. Spôsobené to môže byt' predovšetkým nepredvídanou udalost'ou, kedy sa zamestnanec danej konzultácie nemôže zúčastnit'. Situácia sa však dá vyriešit' nahradením zamestnanca iným, ktorý je k dispozícii, pričom téma (obsah) konzultácie sa zmení tiež. Vyžaduje si to však skúseného konzultanta, ktorý v obmedzenom časovom rozsahu dokáže pripravit' program konzultácie tak, aby vyhovoval zmeneným podmienkam.

\section{Časová náročnost’ projektu implementácie modelu riadenia výkonnosti podnikových procesov}

Projekt tvorby a implementácie modelu riadenia výkonnosti podnikových procesov zvyčajne nadväzuje na vytvorený procesný model, preto v závislosti od stavu procesného riadenia v podniku, ako aj od vel'kosti podniku závisí časová náročnost' projektu implementácie modelu riadenia výkonnosti podnikových procesov. Projekt tvorby a implementácie modelu riadenia výkonnosti podnikových procesov má časové rozpätie spravidla od 1 do 6 mesiacov. Vel'mi vel'a závisí od samotného prístupu vrcholového vedenia podniku, to znamená, ako často sú ochotní spolupracovat' s odbornými konzultantmi. V prípade intenzívnej spolupráce sa aj pri vel'kom počte procesov v podniku dá procesný model a model riadenia výkonnosti podnikových procesov vytvorit' a zaviest' do praxe za pomerne krátky čas (približne $2-3$ mesiace). Časový rozsah takéhoto projektu je však vždy individuálny a ovplyvňujú ho i problémy, ktoré sa môžu vyskytnút' pri jeho realizácii.

Jednou z príčin časovej náročnosti môže byt' chaos vyplývajúci zo snahy podniku okamžite zaviest' procesné riadenie a vytvorit' nový systém riadenia podniku. Zvlášt', ak takéto snahy podnik realizoval bez pomoci odborného konzultanta alebo poradcu. Stáva sa, že manažéri podniku, v ktorom existuje snaha zmenit' doterajší systém riadenia podniku zrealizujú workshop za účelom vyjasnenia si právomocí a zodpovedností a prerozdelenia úloh v podniku. Bez akýchkol'vek informácií, bez skúseností, iba na základe negatívnych ekonomických výsledkov podniku. Doterajšie právomoci a kompetencie ako aj úlohy sa rozdelia medzi existujúcich zamestnancov spontánne (živelne), bez uváženia, čo má za následok, že nepopulárne úlohy ostanú neprerozdelené a nevykonané. Na konci vládne väčší 
chaos ako pred zmenou systému riadenia podniku. Vzhl'adom na časovú rozsiahlost' takéhoto projektu je logické, že na jeho konci sú zamestnanci viac alebo menej otrávení a prejavuje sa tiež výsledok neustáleho „odkladania“ práce na neskôr z dôvodu konzultácií.

\section{Záver}

V príspevku som zamerala pozornost' na problematiku riadenia podnikových procesov a merania ich výkonnosti. Na základe návrhu modelu riadenia strategickej a operatívnej výkonnosti podnikových procesov, identifikácie jeho prvkov a väzieb medzi nimi som formulovala kl'účové predpoklady implementácie, z ktorých model vychádza a identifikovala som problémy, ktoré môžu byt' v budúcnosti potenciálnymi bariérami pri jeho implementácii v praxi. Projekt implementácie modelu riadenia výkonnosti podnikových procesov je pomerne náročný, predpokladá existenciu procesného riadenia v podniku. V období neustálych zmien a tvrdého konkurenčného boja nepostačuje, ak sa podnik zaoberá iba krátkodobou výkonnost'ou, musí zabezpečit' i predpoklady svojej dlhodobej budúcej výkonnosti.

\section{Literatúra:}

[1] ĎUĎÁK, J. 1999. Riadenie prevádzky strojov v pol'nohospodárskych technologických systémov. Nitra : Slovenská pol’nohospodárska univerzita, 1999. 165 s. ISBN 978-80552-0246-4.

[2] MACUROVÁ, P. Logistická dimenze výkonnosti podniků a dodavatelských sítí. In: Výkonnost' organizácie. Prístupy k jej meraniu a hodnoteniu, Ekonomická fakulta. Univerzita Mateja Bela, 2005. S. 196 - 202. ISBN 80-968080-5-2.

[3] PRNO, I. 2002. Teória systémov a riadenia. Turany : P + M, 2002. 194 s. ISBN 80968842-0-9.

[4] RAŠNER, J. Podnikový systém riadenia a jeho výkonnost'. In: Výkonnost' organizácie. Prístupy k jej meraniu a hodnoteniu, Ekonomická fakulta. Univerzita Mateja Bela, 2005. Str. 50 - 54. ISBN 80-968080-5-2.

\section{Klasifikácia JEL: M12, M15, M19}

\section{Ing. Marcela Koval'ová, PhD.}

Odborný asistent

Ekonomická fakulta UMB

Inštitút manažerských systémov so sídlom v Poprade

Francisciho 910/8, 05801 Poprad

e-mail: marcela.kovalova@umb.sk 